\title{
Characteristics of the intestinal microbiome in ankylosing spondylitis
}

\author{
ANCA CARDONEANU $^{1 *}$, SEBASTIAN COZMA $^{2 *}$, CIPRIAN REZUS $^{3 *}$, \\ FLORIN PETRARIU $^{4 *}$, ALEXANDRA MARIA BURLUI ${ }^{1}$ and ELENA REZUS ${ }^{1}$ \\ Departments of ${ }^{1}$ Rheumatology and Physiotherapy, ${ }^{2}$ Surgery (II), ${ }^{3}$ Internal Medicine \\ and ${ }^{4}$ Preventive Medicine and Interdisciplinarity, Grigore T Popa University of Medicine and Pharmacy, \\ Faculty of Medicine, 700115 Iasi, Romania
}

Received February 24, 2021; Accepted March 26, 2021

DOI: $10.3892 / \mathrm{etm} .2021 .10108$

\begin{abstract}
The importance of intestinal microbiota in the development of various systemic diseases has been highlighted over time. Ankylosing spondylitis (AS) is a systemic disease with a complex pathogenesis involving a particular genetic marker and distinctive environmental triggers such as a specific gut dysbiosis. We conducted a prospective case-control study which included 60 subjects from Iasi Rehabilitation Hospital: 28 AS cases and 32 healthy controls. Intestinal microbiota analysis was performed by real-time polymerase chain reaction (qPCR) in stool samples. We performed the quantitative analysis of gut microbiome, focusing both on anti-inflammatory (Bifidobacterium, Lactobacillus, Faecalibacterium prausnitzii) and pro-inflammatory (Bacteroides, Escherichia coli) species. Overall, intestinal bacterial diversity in the AS group was decreased compared to that noted in the control. A significantly decreased level of Clostridium leptum was observed, associated with an increased level of Escherichia coli. We showed correlations between laboratory tests (liver and kidney functional tests, inflammatory syndrome), the presence of HLA-B27, smoker status, the forms of AS with peripheral arthritis vs. pure axial forms and bacterial structures. No significant correlations were shown for disease activity scores, radiological stage of sacroiliitis or for body mass index. Our findings support that the intestinal microbiome in AS patients has a special signature characterized by an inflammatory status. Numerous environmental, genetical, clinical and paraclinical factors can lead to changes in gut bacterial diversity in these cases.
\end{abstract}

Correspondence to: Dr Sebastian Cozma, Department of Surgery (II), Grigore T Popa University of Medicine and Pharmacy, Faculty of Medicine, 16 University Street, 700115 Iasi, Romania E-mail: sebastian.cozma@umfiasi.ro

*Contributed equally

Key words: ankylosing spondylitis, gut microbiome, intestinal dysbiosis, systemic inflammation, enteropathy

\section{Introduction}

Ankylosing spondylitis (AS) is a chronic immune-mediated disease from the larger group of spondyloarthritis ( $\mathrm{SpA})$ characterized mainly by axial damage (1). The pathogenesis of AS includes the presence of a particular genetic marker, human leukocyte antigen (HLA)-B27, that interacts with environmental factors capable of initiating development of the disease (2-4). Many clinical studies based on animal models have attempted to explain the complex pathogenesis of AS, but to date, the pathogenic mechanism of the disease remains partially unknown $(5,6)$.

AS can be considered a systemic condition, presenting both musculoskeletal (axial and peripheral involvement) and extraarticular manifestations, the most common being ocular, digestive, cardiovascular and pulmonary ones. The close link between the gut and SpA is well known; inflammatory bowel disease (IBD) and AS having etiopathogenic similarities and being considered distinct phenotypes of the same immuno-mediated disease $(7,8)$. A high percentage, up to $70 \%$, of patients with AS have subclinical intestinal inflammation and up to $10 \%$ of them will develop a clinically manifested $\operatorname{IBD}(9,10)$.

The importance of the intestinal microbiota in the development of various systemic diseases has been highlighted over time. It has been shown that under germ-free conditions, HLA-B27//2-microglobulin-transgenic rats do not present any manifestation of the disease; by introducing commensal intestinal bacteria in this sterile environment, the development of both intestinal and joint inflammation was observed (11). Furthermore, in this rat model there was evidence of an impaired mucosal immunity (12) and a specific intestinal dysbiosis characterized by decreased species of Rikenellaceae and increased Prevotella species (13).

A recently published article attempts to explain the role of intestinal microbiota in the development of AS based on a literature review (14). Thus, in the first place, is the interaction between the antigen HLA-B27 and the intestinal bacterial structures that can lead to a misfolding of HLA-B27 and to an unfolded protein response of the endoplasmic reticulum $(14,15)$. This unfolded response is responsible for the induction of pro-inflammatory proteins (16) as well as for the 
phenomenon of autophagy (17). Moreover, there is a molecular mimicry between bacterial peptides presented by HLA-B27 and various self-peptides which may induce cross-immune responses $(14,18)$.

On the other hand, changes were observed in the intestinal mucosa characterized by an increased intestinal permeability $(14,19,20)$, by an increased secretion of $\mathrm{A}$ immunoglobulins (IgA) (21) and proinflammatory cytokines mediated by the activation of Th17 lymphocytes (22-25).

Taking all this into consideration, our study aimed to analyze intestinal dysbiosis in patients with AS in terms of composition, highlighting the correlations with different demographic, clinical and paraclinical features.

\section{Patients and methods}

We conducted a prospective, case-control study in Northeastern Romania which included 60 subjects. The enrolled cases were distributed as follows: 28 cases in the AS group and 32 healthy controls. The individuals included in the study were enrolled at the 1st Rheumatology Clinic of the Rehabilitation Hospital Iasi from April 2016 to March 2017. All the included cases expressed their informed consent to participate in the study. Approval was obtained from the Ethics Committees of the Grigore T Popa University of Medicine and Pharmacy and Rehabilitation Hospital Iasi from which the cases were selected.

The inclusion criteria were: Age over 18 years; signed consent by the participant to be included in the study; definite diagnosis of AS. Patients diagnosed with AS met the 1984 modified New York Diagnostic Criteria (26). All subjects included in the analysis completed a food questionnaire regarding the food components on which their diet was based during the last month. The selected group of patients with AS was as homogeneous as possible in terms of diet, excluding cases in which probiotic medication were prescribed.

Exclusion criteria consisted of: Patient refusal to participate in this study, uncertain diagnosis of AS, serious infections in the last 3 months (tuberculosis, Clostridium difficile), colorectal cancer, antibiotic therapy during the last 3 months.

For each case, a monitoring form was completed which included demographic data [name, age, area of origin, ethnicity, occupation, smoking status, body mass index (BMI)], year of diagnosis, family and personal pathological history, and current treatment. The group of patients with AS was divided in two clinical subgroups representing a pure axial form and a form associated with peripheral manifestations. For evaluating disease activity, the BASDAI (Bath Ankylosing Spondylitis Disease Activity Index) and BASFI (Bath Ankylosing Spondylitis Functional Index) scores were used $(1,22)$.

Intestinal microbiota analysis was performed by real-time polymerase chain reaction (qPCR) in stool samples. From each case included in the study, $20 \mathrm{~g}$ of feces was obtained. The stool samples were transported (within a maximum of $4 \mathrm{~h}$ from sampling) to the microbiology laboratory and were frozen at a temperature of $-80^{\circ} \mathrm{C}$ for one week maximum until deoxyribonucleic acid (DNA) extraction.

DNA extraction from fecal samples. For DNA extraction from feces, the GenElute ${ }^{\mathrm{TM}}$ Stool DNA Isolation Kit (Sigma
Aldrich; Merck KGaA) was used. DNA extraction included the following steps: i) From the $20 \mathrm{~g}$ of feces collected from patients, $200 \mathrm{mg}$ was isolated and added to a special extraction tube (Bead Tube) along with $1 \mathrm{ml}$ of Lysis Buffer L; ii) $100 \mu \mathrm{l}$ of another special lysis solution (Lysis Additive A) was added; iii) mixed for $3 \mathrm{~min}$, then centrifuged for $2 \mathrm{~min}$ at $14,000 \mathrm{rpm}$; iv) from the obtained supernatant, $600 \mu 1$ was transferred to another DNA tube (DNAase-free microcentrifuge tube) over which $100 \mu \mathrm{l}$ of Binding Buffer I was added and the mixture was incubated for $10 \mathrm{~min}$ on ice, then centrifuged for $2 \mathrm{~min}$; v) from the newly obtained supernatant, $700 \mu \mathrm{l}$ was separated in a 2-ml tube (DNAase-free microcentrifuge tube) over which $700 \mu$ l of ethanol was added and centrifuged; vi) from the ethanol clarification supernatant, $600 \mu \mathrm{l}$ was separated, introduced into a specific DNA binding tube and centrifuged for $1 \mathrm{~min}$ at $6,000 \mathrm{rpm}$; vii) the DNA-binding column was mixed with $500 \mu \mathrm{l}$ of wash buffer (SK buffer) and centrifuged for $1 \mathrm{~min}$; viii) the washed DNA binding column was introduced into an Elution tube and $50 \mu 1$ of Elution Buffer (E) was added, centrifuged for $2 \mathrm{~min}$ at 2,000 rpm, and then $1 \mathrm{~min}$ at $14,000 \mathrm{rpm}$.

After DNA extraction from the feces, DNA quantity and purity were checked using a NanoDrop spectrophotometer. The purity of the samples was checked using 2 wavelengths: OD $260 / 280_{\mathrm{nm}}$, respectively OD $260 / 230_{\mathrm{nm}}$. The entire phase which consisted in the extraction of pure DNA from feces was carried out in the microbiology laboratory under the Thermo DNA extraction hood.

$q P C R$. Through this study, we tried to highlight the characteristics of different populations of the gut microbiota: Certain genera, species and possibly a phylum. The qPCR reaction targeted different populations of the microbiota: Total bacteria, Bacteroides, Bifidobacterium, Clostridium coccoides (XIVa) (C. Coccoides), Clostridium leptum (IV) (C. Leptum), Faecalibacterium prausnitzii (F. Prausnitzii), Lactobacillus, Escherichia coli (E.Coli) and $\beta$-globin gene used as an internal control. The primer structures were taken from an article published by Wang et al (27) and verified using OligoAnalyzer 3.1 (https://eu.idtdna.com). In addiion, the primer annealing temperature was checked. Table I shows the primer structures and the annealing temperatures.

The qPCR reaction was performed using SYBR Green intercalary fluorochromes method that only bind to double-stranded DNA molecules and included the following steps: i) The amplification reaction was carried out at a final volume of $25 \mu \mathrm{l}$ containing: $9.8 \mu \mathrm{l} \mathrm{SYBR}$ Mix, $0.5 \mu \mathrm{l}$ of each primer at a final concentration of $0.2 \mu \mathrm{M}, 0.5 \mu \mathrm{l}$ fluorochrome ROX (5-carboxy-X-rhodamine), $5 \mu 1$ of bacterial DNA and ultra-pure water to a volume of $20 \mu \mathrm{l}(9.8 \mu \mathrm{l})$; ii) 1 cycle at $95^{\circ} \mathrm{C}$ for $10 \mathrm{~min}$; iii) 40 cycles at $95^{\circ} \mathrm{C}$ for $10 \mathrm{sec}$; iv) $30 \mathrm{sec}$ at normalization temperature; and v) $30 \mathrm{sec}$ at $72^{\circ} \mathrm{C}$, the annealing temperature.

In order to reduce the quantitative error of detected bacteria and to characterize changes in bacterial copies, abundance of $16 \mathrm{~S}$ rRNA gene was calculated from standard curves. Specific bacterial groups are expressed as a percentage of total bacteria determined by universal primers. The standard curve was constructed from decimal dilutions of the 16S rRNA amplicon using reference strains for each bacterial target. Based on 
Table I. Bacterial-specific 16S rRNA primers and the annealing temperatures.

\begin{tabular}{|c|c|c|c|}
\hline Bacterial species & Primer direction & Sequence (5' to $\left.3^{\prime}\right)$ & Annealing temp. $\left({ }^{\circ} \mathrm{C}\right)$ \\
\hline \multirow[t]{2}{*}{ All bacteria } & $\mathrm{F}$ & ACTCCTACGGGAGGCAGCAGT & 61 \\
\hline & $\mathrm{R}$ & GTATTACCGCGGCTGCTGGCAC & \\
\hline \multirow[t]{2}{*}{ Bacteroides } & $\mathrm{F}$ & GTCAGTTGTGAAAGTTTGC & 61.5 \\
\hline & $\mathrm{R}$ & CAATCGGGAGTTCTTCGTG & \\
\hline \multirow[t]{2}{*}{ Bifidobacterium } & $\mathrm{F}$ & AGGGTTCGATTCTGCTCAG & 62 \\
\hline & $\mathrm{R}$ & CATCCGGCATTACCACCC & \\
\hline \multirow[t]{2}{*}{ C. coccoides (XIVa) } & $\mathrm{F}$ & AAATGACGGTACCTGACTAA & 60.7 \\
\hline & $\mathrm{R}$ & CTTTGAGTTTCATTCTTGCGAA & \\
\hline \multirow[t]{2}{*}{ C. leptum (IV) } & $\mathrm{F}$ & GTTGACAAAACGGAGGAAGG & 60 \\
\hline & $\mathrm{R}$ & GACGGGCGGTGTGTACAA & \\
\hline \multirow[t]{2}{*}{ F.prausnitzii } & $\mathrm{F}$ & AGATGGCCTCGCGTCCGA & 61.5 \\
\hline & $\mathrm{R}$ & CCGAAGACCTTCTTCCTCC & \\
\hline \multirow[t]{2}{*}{ Lactobacillus } & $\mathrm{F}$ & GCAGCAGTAGGGAATCTTCCA & 61.5 \\
\hline & $\mathrm{R}$ & GCATTYCACCGCTACACATG & \\
\hline \multirow[t]{2}{*}{ E. coli } & $\mathrm{F}$ & GTTAATACCTTTGCTCATTGA & 61 \\
\hline & $\mathrm{R}$ & ACCAGGGTATCTAATCCTGTT & \\
\hline \multirow[t]{2}{*}{$\beta$-globin } & $\mathrm{F}$ & CAACTTCATCCACGTTCACC & - \\
\hline & $\mathrm{R}$ & GAAGAGCCAAGGACAGGTAC & \\
\hline
\end{tabular}

F, forward; R, reverse.
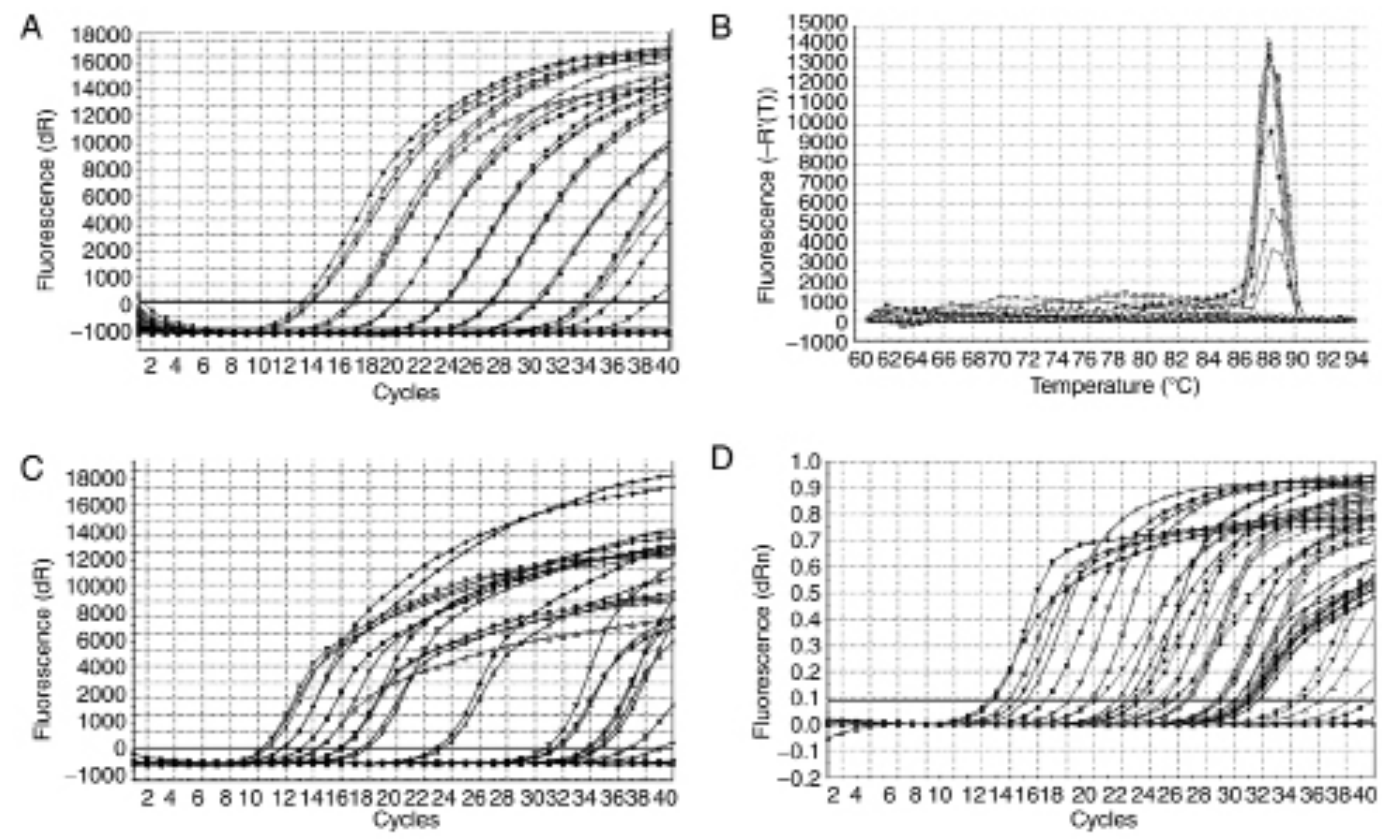

Figure 1. (A) Standard curve of the amplification (triplicates). (B) Dissociation curve. (C) Amplification curve for E. coli. (D) Amplification curve for Bacteroides.

this standard curve, all sample amplification was performed (Fig. 1A). The dissociation and amplification curves confirmed that DNA amplification occurred specifically (Fig. 1B-D).

Following extraction, pure DNA was obtained by spectrophotometer analysis (OD 260/280 nm, OD 260/230 nm). Data on DNA concentration, quantity and purity are documented in Table II.
Statistical analysis. The obtained data were centralized in the SPSS 22.0 database (IBM Corp.). Statistical analysis used both descriptive and analytical methods at $95 \%$ significance (CI 95\% CI). The statistical tests used included ANOVA and Chi-square tests, linear regression, and odds ratio. For comparisons between groups having a non-linear distribution, Mann-Whitney U test and Kruskal-Wallis method were used. 
Table II. Concentration, quantity and purity of the extracted DNA.

\begin{tabular}{lllcccc}
\hline \multirow{2}{*}{ DNA } & & & & & \multicolumn{2}{c}{$95 \% \mathrm{CI}$} \\
\cline { 5 - 7 } Concentration $(\mathrm{ng} / \mu \mathrm{l})$ & Cases & $\mathrm{N}$ & Median & Standard deviation & Min & Max \\
\cline { 4 - 7 } Quantity $(\mu \mathrm{g})$ & AS & 28 & 48.61 & 24.81 & 38.98 & 58.23 \\
& Control & 32 & 36.86 & 26.34 & 27.36 & 46.36 \\
Purity 260/280 nm & AS & 28 & 2.91 & 1.48 & 2.33 & 3.49 \\
\multirow{3}{*}{ Purity 260/230 nm } & Control & 32 & 2.21 & 1.58 & 1.64 & 2.78 \\
& AS & 28 & 1.97 & 0.083 & 1.94 & 2.008 \\
& Control & 32 & 2.03 & 0.17 & 1.96 & 2.09 \\
& AS & 28 & 0.48 & 0.35 & 0.34 & 0.62 \\
& Control & 32 & 0.44 & 0.33 & 0.32 & 0.56 \\
\hline
\end{tabular}

AS, ankylosing spondylitis; DNA, deoxyribonucleic acid; CI, confidence interval.

A P-value less than $0.05(\mathrm{P}<0.05)$ was considered statistically significant.

\section{Results}

Characteristics of the study group. The demographic, clinical and paraclinical characteristics of the cases included in this study are presented in Table III. The compared groups were homogeneous in terms of area of origin, smoking, social status and BMI. We observed a higher percentage of male sex and a younger age in the AS group. All cases were overweight.

Characteristics of the intestinal dysbiosis in the study groups. The microbiota analysis was performed for each of the two groups, being calculated quantitatively. The data in Table IV show the quantitative results expressed logarithmically.

In order to be able to compare the bacterial groups according to each arm, the non-parametric Kruskal Wallis test was used. Thus, applying the test for all combinations of 2 groups, the following results were found. Statistically significant data were found only for C. leptum $(\mathrm{P}=0.019)$ and $E$. coli $(\mathrm{P}=0.013)$. In cases with AS, a significantly decreased level of $C$. leptum was observed, associated with an increased level of $E$. coli. The other analyzed microbial populations did not show significant statistical differences with the control arm. The group of cases with AS also showed a decreased microbial diversity than the control group, but without any statistical value (Fig. 2).

Using the Spearman correlation coefficient, significant correlations were found between paraclinical tests (liver and kidney function, inflammatory syndrome) and bacterial species (Table V). Thus, ESR and CRP were inversely correlated with the level of Bacteroides and directly proportional to $C$. coccoides and $C$. leptum. Serum transaminases levels were directly proportional to total bacteria $(\mathrm{P}=0.001)$. Only the ALT level was inversely correlated with Bifidobacterium $(\mathrm{P}=0.006)$. Creatinine was inversely correlated with Bacteroides $(\mathrm{P}=0.045)$ and $E$. coli $(\mathrm{P}=0.027)$ and directly proportional to C. coccoides $(\mathrm{P}<0.001)$ and C. leptum $(\mathrm{P}=0.005)$.
No correlations were found between the degree of radiological sacroiliitis and bacterial groups $(\mathrm{P}=0.053$, Kruskal-Wallis test) or between BMI and bacterial populations $(\mathrm{P}=0.366)$.

Of the 28 cases with AS, 22 patients tested positive for the antigen HLA-B27 (human leucocyte antigen B27). Following the statistical analysis (Mann-Whitney test), significant correlations were highlighted between HLA-B27 and Lactobacillus $(\mathrm{P}=0.027)$ and E. coli $(\mathrm{P}=0.004)$ (Table VI).

Other significant data were recorded in relation to smoker status. Thus, correlations between $C$. coccoides $(\mathrm{P}=0.033)$ and Bifidobacterium $(\mathrm{P}=0.006)$ were found in the arm of smokers diagnosed with AS. The level of $C$. coccoides was decreased, while Bifidobacterium was increased. On the other hand, correlations with a decreased level of $F$. prausnitzii $(\mathrm{P}=0.027)$ were found for active smokers in the control group (Table VII).

Using the Spearman correlations, we aimed to ascertain whether there were correlations between the disease activity quantified by BASDAI and BASFI scores and the bacterial populations. We did not find statistically significant data between these scores and the bacteria species (Table VIII). It should be mentioned that the patients included in the analysis had a moderate disease activity, with an average BASDAI of $4.83(3.87-5.7995 \% \mathrm{CI})$ and an average BASFI of 9.11 (4.44-13.78 95\% CI).

According to the form of the disease, patients with AS were divided into an axial and a form with peripheral arthritis. Using the Mann-Whitney statistical test, significant data were found only for the Bifidobacterium bacterial group $(\mathrm{P}=0.035)$. Thus, in the peripheral form of AS there was a significant decrease of Bifidobacterium compared to the axial form (Table IX).

Regarding the treatment followed by patients with AS, all of them were receiving drug therapy at the time of enrollment in the study. Thus, most cases $(n=19 ; 67.85 \%)$ were receiving anti-TNF $\alpha$ treatment, 5 cases (17.85\%) were receiving sulfasalazine (SSZ) therapy, and 4 patients (14.28\%) were receiving only symptomatic treatment with nonsteroidal anti-inflammatory drugs (NSAIDs). Because the number of cases was relatively small for each therapy, the statistical analysis did not have consistency. Thus, we grouped the 
Table III. Demographic characteristics of the AS and control groups.

\begin{tabular}{|c|c|c|c|}
\hline Characteristic & Subcategory & AS $(n=28)$ & Control $(n=32)$ \\
\hline \multirow[t]{2}{*}{ Sex, n (\%) } & Female & $11(39.3)$ & $20(62.5)$ \\
\hline & Male & $17(60.7)$ & $12(37.5)$ \\
\hline \multirow[t]{2}{*}{ Age, years } & Mean (SD) & $52.1(13.6)$ & $61.5(10)$ \\
\hline & Range & $46-57$ & $57-65$ \\
\hline \multirow[t]{2}{*}{ Area of origin, n (\%) } & Urban & $20(71.4)$ & $16(50)$ \\
\hline & Rural & $8(28.6)$ & $16(50)$ \\
\hline \multirow[t]{3}{*}{ Smoking status, n (\%) } & Smokers & $10(35.7)$ & $12(37.5)$ \\
\hline & Ex-smokers & $2(7.1)$ & $6(18.7)$ \\
\hline & Non-smokers & $16(57.2)$ & $14(43.8)$ \\
\hline \multirow[t]{2}{*}{ BMI $\left(\mathrm{kg} / \mathrm{m}^{2}\right)$} & Mean (SD) & $28.08(5.2)$ & $26.9(3.7)$ \\
\hline & Range & 26.04-30.1 & $25.6-28.3$ \\
\hline \multirow[t]{2}{*}{ Form of disease $(\mathrm{n}, \%)$} & Axial & $17(60.7)$ & NA \\
\hline & Peripheral & $11(39.3)$ & NA \\
\hline \multirow[t]{2}{*}{ BASDAI } & Mean & 4.83 & NA \\
\hline & CI $95 \%$ & $3.87-5.79$ & NA \\
\hline \multirow[t]{2}{*}{ BASFI } & Mean & 9.11 & NA \\
\hline & CI $95 \%$ & 4.44-13.78 & NA \\
\hline \multirow[t]{2}{*}{ Hemoglobin (g/dl) } & Mean (SD) & $13.01(0.9)$ & $13.5(1.6)$ \\
\hline & Range & $12.6-13.3$ & $12.9-14.1$ \\
\hline \multirow[t]{2}{*}{ Iron $(\mu \mathrm{g} / \mathrm{dl})$} & Mean (SD) & $93.8(31.1)$ & $77.7(22.6)$ \\
\hline & Range & 81.7-105.8 & $69.6-85.9$ \\
\hline \multirow[t]{2}{*}{ Leukocytes $\left(/ \mathrm{mm}^{3} \times 10^{3}\right)$} & Mean (SD) & $7.1(1.8)$ & $6.5(1.03)$ \\
\hline & Range & $6.4-7.8$ & $6.1-6.8$ \\
\hline \multirow[t]{2}{*}{ Thrombocytes $\left(/ \mathrm{mm}^{3} \times 10^{3}\right)$} & Mean (SD) & $293.6(75.6)$ & $250.1(35.5)$ \\
\hline & Range & $264.2-322.9$ & $237.2-262.9$ \\
\hline \multirow[t]{2}{*}{$\mathrm{ESR}(\mathrm{mm} / \mathrm{h})$} & Mean (SD) & $23.4(12.7)$ & $16.4(10.5)$ \\
\hline & Range & $18.5-28.3$ & $12.6-20.2$ \\
\hline \multirow[t]{2}{*}{ CRP (mg/dl) } & Mean (SD) & $0.9(1.3)$ & $0.8(0.9)$ \\
\hline & Range & $0.4-1.4$ & $0.4-1.1$ \\
\hline \multirow[t]{2}{*}{ AST (IU/l) } & Mean (SD) & $28.6(16.4)$ & $24.3(15.9)$ \\
\hline & Range & 22.2-35.07 & $18.5-30.05$ \\
\hline \multirow[t]{2}{*}{$\operatorname{ALT}(\mathrm{IU} / \mathrm{l})$} & Mean (SD) & $24.9(12.3)$ & $27.5(15.8)$ \\
\hline & Range & $20.1-29.7$ & $21.8-33.2$ \\
\hline \multirow[t]{2}{*}{ GGT (U/l) } & Mean (SD) & $42.9(23.7)$ & $32.8(19.01)$ \\
\hline & Range & $33.7-52.1$ & $26.02-39.7$ \\
\hline \multirow[t]{2}{*}{ Total serum proteins $(\mathrm{g} / \mathrm{dl})$} & Mean (SD) & $7.2(0.4)$ & $7.2(0.4)$ \\
\hline & Range & $7.07-7.4$ & $7.06-7.4$ \\
\hline \multirow[t]{2}{*}{ Creatinine (mg/dl) } & Mean (SD) & $0.9(0.2)$ & $0.9(0.1)$ \\
\hline & Range & $0.8-1$ & 0.8-0.9 \\
\hline
\end{tabular}

AS, ankylosing spondylitis; SD, standard deviation; BMI, body mass index; ESR, erythrocyte sedimentation rate; CRP, C reactive protein; AST, aspartate transaminase; ALT, alanine transaminase; GGT, $\gamma$-glutamyltransferase; NA, non-applicable; CI, confidence interval; BASDAI, Bath Ankylosing Spondylitis Disease Activity Index; BASFI, Bath Ankylosing Spondylitis Functional Index.

patients as follows: the group that had NSAID treatment $(n=4)$ and those on immunosuppressive treatment (SSZ + antiTNF $\alpha$; $\mathrm{n}=24$ ). It was observed that patients who were treated only with NSAIDs showed a decrease in bacterial diversity $(\mathrm{P}=0.560)$, in Bifidobacterium $(\mathrm{P}<0.001)$ and Lactobacillus $(\mathrm{P}=0.382)$ followed by an increase in Bacteroides $(\mathrm{P}<0.001)$, C. coccoides $(\mathrm{P}=0.005), C$. leptum $(\mathrm{P}<0.001), F$. prausnitzii
$(\mathrm{P}=0.001)$ and $E$. coli $(\mathrm{P}=0.001)$. All these data are presented in Table $\mathrm{X}$ and Fig. 3.

\section{Discussion}

The present study analyzed different populations of the gut microbiome in patients with ankylosing spondylitis (AS): 
Table IV. Quantitative characteristics of the microbial populations analyzed in the AS and control groups.

\begin{tabular}{llcccc}
\hline & & & & \multicolumn{2}{c}{$95 \%$ CI } \\
\cline { 5 - 6 } Bacterial population & Study group & Mean & Standard deviation & Min & Max \\
\hline All bacteria & AS & $2.18 \mathrm{E}+10$ & $2.27 \mathrm{E}+10$ & $1.3 \mathrm{E}+10$ & $3.06 \mathrm{E}+10$ \\
& Control & $4.13 \mathrm{E}+10$ & $3.77 \mathrm{E}+10$ & $2.77 \mathrm{E}+10$ & $5.49 \mathrm{E}+10$ \\
Bacteroides & AS & $3.57 \mathrm{E}+09$ & $4.37 \mathrm{E}+09$ & $1.88 \mathrm{E}+09$ & $5.26 \mathrm{E}+09$ \\
& Control & $7.5 \mathrm{E}+09$ & $6.96 \mathrm{E}+09$ & $4.99 \mathrm{E}+09$ & $1.00 \mathrm{E}+10$ \\
C. coccoides & AS & $5.13 \mathrm{E}+09$ & $5.47 \mathrm{E}+09$ & $3.01 \mathrm{E}+09$ & $7.25 \mathrm{E}+09$ \\
& Control & $1.28 \mathrm{E}+10$ & $1.49 \mathrm{E}+10$ & $7.44 \mathrm{E}+09$ & $1.82 \mathrm{E}+10$ \\
C. leptum & AS & $2.72 \mathrm{E}+09$ & $2.57 \mathrm{E}+09$ & $1.72 \mathrm{E}+09$ & $3.72 \mathrm{E}+09$ \\
& Control & $9.64 \mathrm{E}+09$ & $1.19 \mathrm{E}+10$ & $5.36 \mathrm{E}+09$ & $1.39 \mathrm{E}+10$ \\
F. prausnitzii & AS & $2.16 \mathrm{E}+09$ & $2.73 \mathrm{E}+09$ & $1.1 \mathrm{E}+09$ & $3.22 \mathrm{E}+09$ \\
Bifidobacterium & Control & $5.51 \mathrm{E}+09$ & $5.13 \mathrm{E}+09$ & $3.66 \mathrm{E}+09$ & $7.36 \mathrm{E}+09$ \\
& AS & $3.72 \mathrm{E}+08$ & $3.93 \mathrm{E}+08$ & $2.2 \mathrm{E}+08$ & $5.25 \mathrm{E}+08$ \\
Lactobacillus & Control & $4.25 \mathrm{E}+08$ & $3.11 \mathrm{E}+08$ & $3.13 \mathrm{E}+08$ & $5.38 \mathrm{E}+08$ \\
\multirow{3}{*}{ E. coli } & AS & $5.21 \mathrm{E}+08$ & $5.63 \mathrm{E}+08$ & $3.02 \mathrm{E}+08$ & $7.39 \mathrm{E}+08$ \\
& Control & $8.07 \mathrm{E}+08$ & $7.72 \mathrm{E}+08$ & $5.29 \mathrm{E}+08$ & $1.09 \mathrm{E}+09$ \\
& AS & $1.06 \mathrm{E}+09$ & $1.09 \mathrm{E}+09$ & $6.41 \mathrm{E}+08$ & $1.48 \mathrm{E}+09$ \\
& Control & $8.72 \mathrm{E}+08$ & $9.43 \mathrm{E}+08$ & $5.32 \mathrm{E}+08$ & $1.21 \mathrm{E}+09$ \\
\hline
\end{tabular}

CI, confidence interval; AS, ankylosing spondylitis.

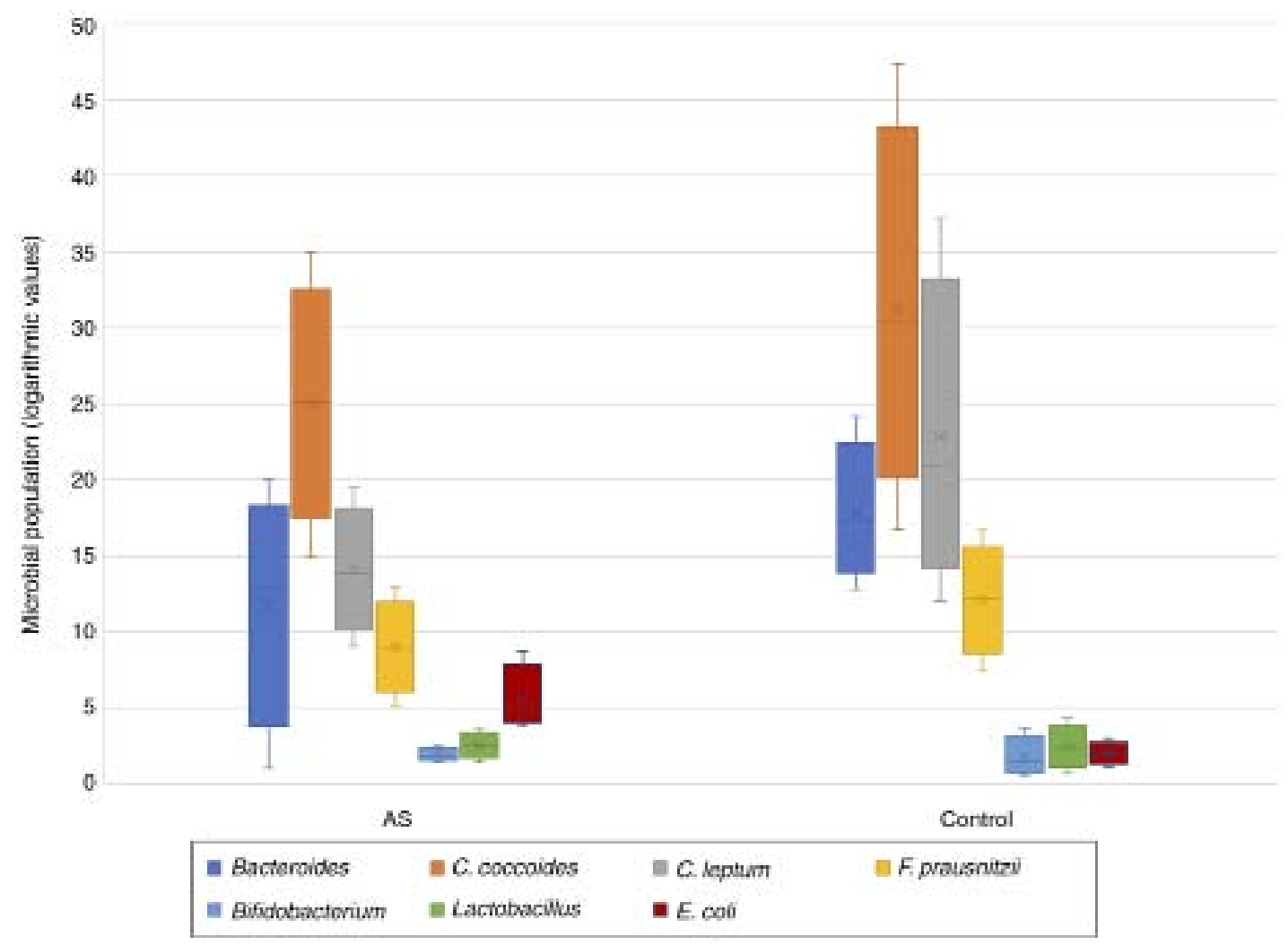

Figure 2. Microbial populations highlighted in the study cases. AS, ankylosing spondylitis.

Certain species, genera and possibly a phylum compared to a control group formed by healthy individuals. The two study arms were carefully selected to be as homogeneous as possible. Analysis of the intestinal microbiome was performed in the feces using the qPCR technique. We took into consideration the quantitative analysis of the microbiome, focusing 


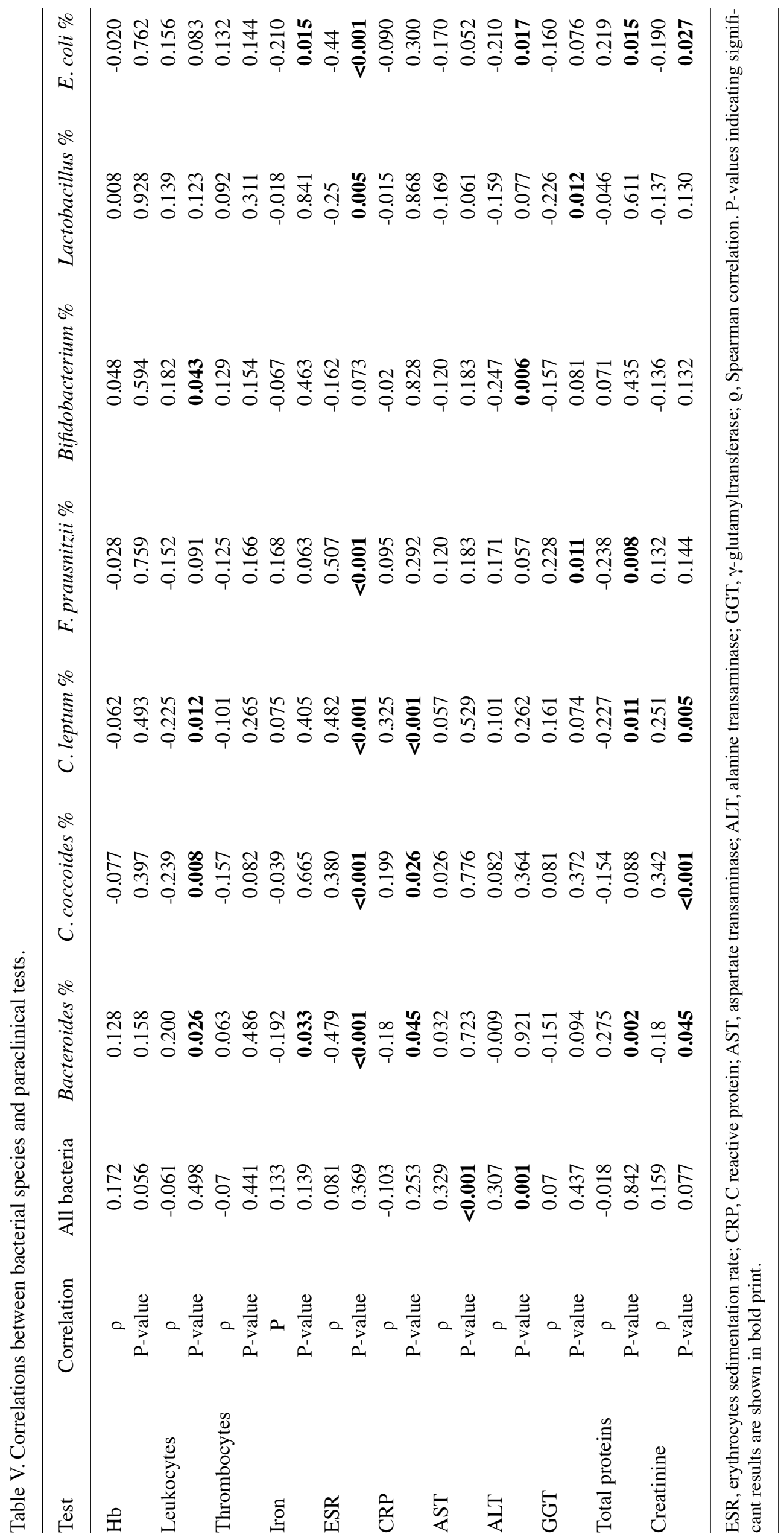



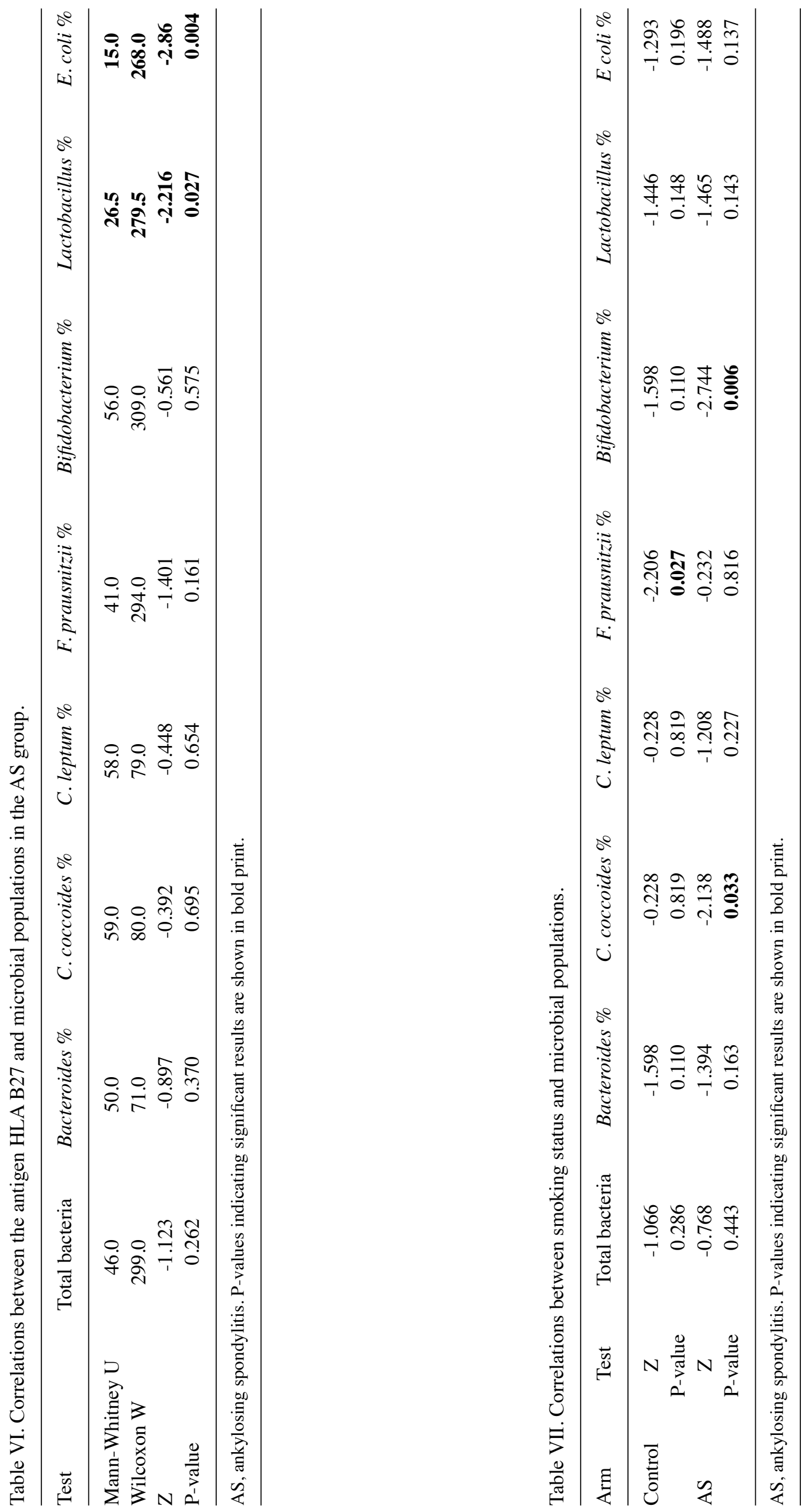
Table VIII. Correlations between disease activity and microbial populations in the AS group.

\begin{tabular}{|c|c|c|c|}
\hline Score & Microbial population & Spearman coefficient & P-value \\
\hline \multirow[t]{8}{*}{ BASDAI } & All bacteria & -0.336 & 0.080 \\
\hline & Bacteroides \% & -0.371 & 0.052 \\
\hline & C.coccoides $\%$ & 0.111 & 0.573 \\
\hline & C. leptum \% & 0.340 & 0.077 \\
\hline & F.prausnitzii \% & -0.371 & 0.052 \\
\hline & Bifidobacterium \% & 0.183 & 0.351 \\
\hline & Lactobacillus \% & 0.331 & 0.085 \\
\hline & E. coli $\%$ & 0.309 & 0.110 \\
\hline \multirow[t]{8}{*}{ BASFI } & All bacteria & -0.018 & 0.927 \\
\hline & Bacteroides \% & -0.061 & 0.758 \\
\hline & C. coccoides $\%$ & 0.053 & 0.788 \\
\hline & C. leptum \% & 0.010 & 0.960 \\
\hline & F.prausnitzii \% & 0.104 & 0.597 \\
\hline & Bifidobacterium \% & 0.048 & 0.809 \\
\hline & Lactobacillus \% & 0.019 & 0.924 \\
\hline & E. coli $\%$ & -0.015 & 0.941 \\
\hline
\end{tabular}

AS, ankylosing spondylitis; BASFI, Bath Ankylosing Spondylitis Functional Index; BASDAI, Bath Ankylosing Spondylitis Disease Activity Index.

Table IX. Correlations between microbial populations and the form of AS.

\begin{tabular}{|c|c|c|c|c|}
\hline Microbial population & Form of AS & Mean rank & Sum of ranks & P-value \\
\hline \multirow[t]{2}{*}{ Total bacteria } & Axial & 23.94 & 766.00 & \multirow[t]{2}{*}{0.451} \\
\hline & Peripheral & 20.69 & 269.00 & \\
\hline \multirow[t]{2}{*}{ Bacteroides \% } & Axial & 22.44 & 718.00 & \multirow[t]{2}{*}{0.652} \\
\hline & Peripheral & 24.38 & 317.00 & \\
\hline \multirow[t]{2}{*}{ C. coccoides $\%$} & Axial & 23.41 & 749.00 & \multirow[t]{2}{*}{0.744} \\
\hline & Peripheral & 22.00 & 286.00 & \\
\hline \multirow[t]{2}{*}{ C. leptum \% } & Axial & 23.19 & 742.00 & \multirow[t]{2}{*}{0.880} \\
\hline & Peripheral & 22.54 & 293.00 & \\
\hline \multirow[t]{2}{*}{ F.prausnitzii \% } & Axial & 23.09 & 739.00 & \multirow[t]{2}{*}{0.940} \\
\hline & Peripheral & 22.77 & 296.00 & \\
\hline \multirow[t]{2}{*}{ Bifidobacterium \% } & Axial & 25.63 & 820.00 & \multirow[t]{2}{*}{0.035} \\
\hline & Peripheral & 16.54 & 215.00 & \\
\hline \multirow[t]{2}{*}{ Lactobacillus \% } & Axial & 23.80 & 761.50 & \multirow[t]{2}{*}{0.522} \\
\hline & Peripheral & 21.04 & 273.50 & \\
\hline \multirow[t]{2}{*}{ E. coli \% } & Axial & 23.66 & 757.00 & \multirow[t]{2}{*}{0.598} \\
\hline & Peripheral & 21.38 & 278.00 & \\
\hline
\end{tabular}

AS, ankylosing spondylitis. P-values indicating significant results are shown in bold print.

both on bacterial structures having an anti-inflammatory role (Bifidobacterium, Lactobacillus, F. prausnitzii), and on some with pro-inflammatory actions that favor intestinal and systemic inflammation (Bacteroides, E. coli).

Following the data analysis, intestinal bacterial diversity in the AS group was decreased compared to the control. Significant data were highlighted only for 2 bacterial species.
A significant numerical increase was observed for $E$. coli associated with a decrease in C. leptum.

The data in the literature regarding gut dysbiosis in AS are contradictory. Our results are in agreement with other studies. Zhang et al (28) investigated fecal microbiota in 103 cases of $\mathrm{AS}$ and concluded that alpha diversity in these cases was no different from the control group. Similar to our results, they 
Table X. Quantitative analysis of the microbiome according to the treatment followed by patients with AS.

\begin{tabular}{|c|c|c|c|c|c|c|c|}
\hline \multirow[b]{2}{*}{ Microbial population } & \multirow[b]{2}{*}{ Treatment } & \multirow[b]{2}{*}{ Mean } & \multicolumn{2}{|c|}{$95 \% \mathrm{CI}$} & \multirow[b]{2}{*}{ Median } & \multirow[b]{2}{*}{ Standard deviation } & \multirow[b]{2}{*}{ P-value } \\
\hline & & & Min & Max & & & \\
\hline \multirow[t]{2}{*}{ Total bacteria } & IS & $2.31 E+10$ & $7.36 \mathrm{E}+09$ & $3.88 \mathrm{E}+10$ & $1.31 \mathrm{E}+10$ & $2.48 \mathrm{E}+10$ & 0.560 \\
\hline & NSAIDs & $1.82 \mathrm{E}+10$ & $1.44 \mathrm{E}+10$ & $2.2 \mathrm{E}+10$ & $1.66 \mathrm{E}+10$ & $5.95 \mathrm{E}+09$ & \\
\hline \multirow{2}{*}{ Bacteroides \% } & IS & 26.90 & 24.51 & 29.29 & 28.06 & 3.76 & $<0.001$ \\
\hline & NSAIDs & 40.91 & 40.41 & 41.42 & 41.00 & 0.79 & \\
\hline \multirow[t]{2}{*}{ C. coccoides $\%$} & IS & 19.51 & 17.18 & 21.84 & 18.06 & 3.66 & 0.005 \\
\hline & NSAIDs & 24.09 & 23.66 & 24.53 & 23.94 & 0.69 & \\
\hline \multirow[t]{2}{*}{ C. leptum \% } & IS & 7.79 & 7.12 & 8.47 & 7.42 & 1.06 & $<0.001$ \\
\hline & NSAIDs & 12.37 & 11.48 & 13.26 & 12.20 & 1.40 & \\
\hline \multirow[t]{2}{*}{ F.prausnitzii \% } & IS & 3.09 & 2.54 & 3.63 & 3.03 & 0.85 & 0.001 \\
\hline & NSAIDs & 4.46 & 4.11 & 4.81 & 4.19 & 0.55 & \\
\hline \multirow{2}{*}{ Bifidobacterium \% } & IS & 3.33 & 2.87 & 3.79 & 2.97 & 0.72 & $<0.001$ \\
\hline & NSAIDs & 1.48 & 1.28 & 1.68 & 1.50 & 0.31 & \\
\hline \multirow[t]{2}{*}{ Lactobacillus \% } & IS & 3.10 & 2.64 & 3.57 & 3.32 & 0.72 & 0.382 \\
\hline & NSAIDs & 2.95 & 2.66 & 3.24 & 3.00 & 0.45 & \\
\hline \multirow[t]{2}{*}{ E. coli $\%$} & IS & 14.37 & 13.48 & 15.26 & 14.20 & 1.40 & 0.001 \\
\hline & NSAIDs & 20.52 & 18.40 & 22.64 & 21.81 & 3.33 & \\
\hline
\end{tabular}

AS, ankylosing spondylitis; NSAIDs, nonsteroidal anti-inflammatory drugs; CI, confidence interval; IS, immunosuppressive. P-values indicating significant results are shown in bold print.

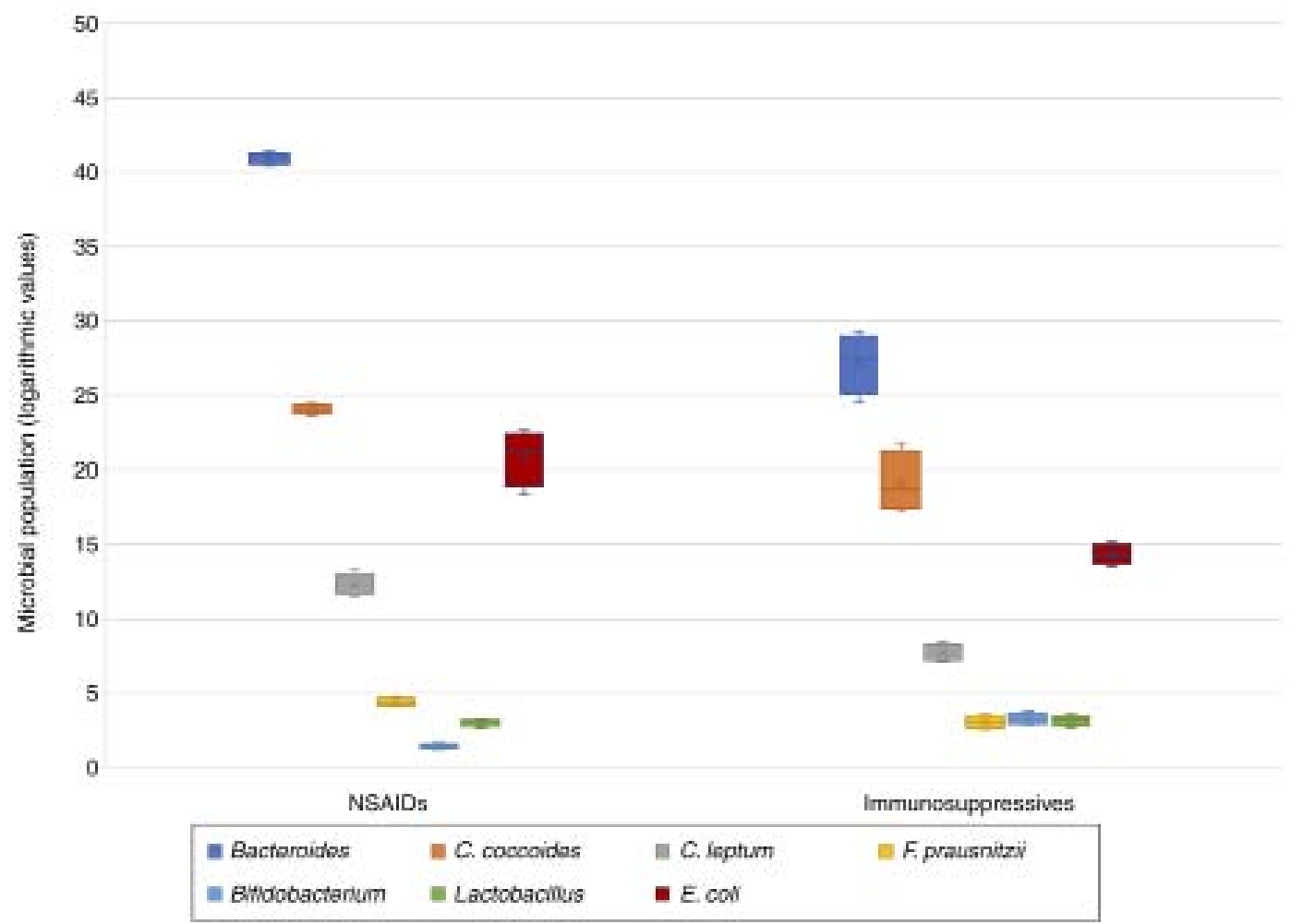

Figure 3. Quantitative analysis of the microbiome according to the treatment followed by the patients with AS. AS, ankylosing spondylitis; NSAIDs, nonsteroidal anti-inflammatory drugs.

showed a decrease in Clostridium_XIVb, but an increase in Bacteroides. Breban et al (29) analyzed the intestinal microbiota in 2 cohorts: rheumatoid arthritis and SA compared to a control group. They showed an overall decreased microbial diversity in both groups, followed by a significant increase in Ruminococcus gnavus in SA. 
Numerous data in the literature support this reduction in intestinal microbial diversity in patients with chronic inflammatory autoimmune diseases $(30,31)$. However, there are several studies that have shown an increase in intestinal bacteria in patients with SA, especially in those having associated intestinal inflammation $(10,32)$.

We demonstrated a close link between liver and kidney function and the analyzed bacteria. Serum transaminases levels were directly proportional to total bacteria. Only the ALT level was inversely correlated with Bifidobacterium. Serum creatinine was inversely correlated with Bacteroides and $E$. coli and directly proportional with $C$. coccoides and C. leptum.

The close connection between the intestine and the liver is a certainty, with many authors reporting about the presence of a liver-intestine axis (33-36). The composition of the intestinal microbiota can modulate chronic liver diseases by i) the production of metabolites, by altering the integrity of the mucosal barrier, ii) by the portal system or iii) by the liver-intestinal immune link (37).

On the other hand, important studies have highlighted the existence of a 'colo-renal system' that can influence each other. The intestinal microbiota can alter renal function, contributing to the development of many pathologies. There is a communication between various intestinal bacterial groups and the cells of the renal parenchyma, which causes a disturbance of the normal renal molecular processes, leading to the appearance of kidney diseases (38-40).

The presence of systemic inflammation was quantified by measuring the acute phase reactants: ESR and CRP. Most often, the normal values of these biological constants are associated with low activity or remission of inflammatory joint diseases. Moreover, they are directly proportional to the disease activity quantified in our study by BASDAI and BASFI scores. Following analysis, ESR and CRP were inversely correlated with the level of Bacteroides and directly proportional to $C$. coccoides and $C$. leptum.

Two studies that are part of the RISTOMED project (Impact of personalized diet and probiotic supplementation on inflammation, nutritional parameters and intestinal microbiota) $(41,42)$ analyzed the correlations between the composition of the intestinal microbiota and various clinical parameters, including inflammatory markers. The study included 125 cases divided into a group with low inflammation and a group with moderate-high inflammation. At the level of intestinal microbiota, the Bifidobacterium and Clostridium group IV species were analyzed. The results showed, in the arm with low inflammation, a decrease in Bifidobacterium followed by an increase in Clostridium IV and the strong correlation with the level of acute phase reactants.

Regarding disease activity, we did not find significant correlations between BASDAI and BASFI scores and the bacteria species. Our results are consistent with other studies that have not shown an association between disease activity or function and intestinal dysbiosis (43). Moreover, these studies showed similarities regarding the highlighted bacterial species, namely an increase in E. coli and a decrease in Clostridium, $F$. prausnitzii and Bacteroides (4,44-46). On the other hand, many data support the close link between the activity of AS and the composition of the intestinal microbiota $(29,32)$ and between gut inflammation and disease activity in AS $(47,48)$.

Considering the genetic predisposition, significant correlations were found between the antigen HLA-B27 and Lactobacillus, respectively E. coli. The levels of Lactobacillus and E. coli were decreased in patients tested positive for the HLA B27 antigen. The ability of this antigen to modulate the intestinal microbiota in transgenic laboratory animals has been demonstrated and published recently (13). Intestinal dysbiosis in HLA-B27-positive laboratory animals was characterized by a decrease in Firmicutes followed by a significant increase in Proteobacteria group, of which E. coli takes part (49). Moreover, Breban et al (29) showed a different intestinal dysbiosis in members of the same family depending on the presence or absence of the HLA-B27 antigen.

Further correlations between gut microbiota composition and clinical parameters included the following data: The BMI, radiological sacroiliitis, smoking status, disease phenotype and the treatment. No correlations were found between the degree of radiological sacroiliitis and bacterial groups or between BMI and gut microbiome. A study published in 2018 highlighted the analysis of the intestinal microbiota in 61 cases of obese people. Intestinal dysbiosis was characterized by a decrease in microbial diversity which correlated with various metabolic parameters (50). Many of the published results are contradictory. Some support a decrease in diversity in the phyla group, others do not show significant differences between normal and obese people. Many authors have shown an increase in Firmicutes followed by a decrease in Bacteroides in cases of obesity $(51,52)$. Kasai et al showed an increase in the diversity of intestinal microbiota in cases of obesity (53). Angelakis et al observed a numerical increase in anaerobic bacteria in obese patients (54). Hu and colleagues found no significant differences between normal and obese individuals in the Bacteroidetes, Firmicutes, and Proteobacteria groups (55).

In the present study, significant data were recorded in relation to smoker status. Correlations between $C$. coccoides and Bifidobacterium were found in the arm of smokers diagnosed with AS. The level of $C$. coccoides was decreased, while Bifidobacterium was increased. On the other hand, correlations with a decreased level of $F$. prausnitzii were found for active smokers in the control group. The relationship between smoking and IBD is well known. This connection is not fully understood, but the alteration of the intestinal microbiota, as well as of the innate and adaptative immune system, has been incriminated (56).

In a recently published meta-analysis (57), the intestinal microbiota was analyzed in healthy smokers. The authors noted a decrease in the diversity of the intestinal microbiome characterized by a decrease in Bifidobacterium and Lactobacillus species and an increase in Bacteroides, Clostridium and Prevotella. Intestinal dysbiosis caused by smoking was similar to IBD dysbiosis.

In the present study, according to the form of the disease, significant data were found only for the Bifidobacterium bacterial group. In the peripheral form there was a significant decrease in Bifidobacterium compared to the axial form of AS. 
Differences in the intestinal microbiome according to disease phenotype were also observed in a study by Chen et al (58). They noted an increase in Prevotella in axial disease and increased Collinsella, Streptococcus and Comamonas in the peripheral form of AS.

In the present study, the final data focused on the correlations between the composition of the intestinal microbiome and treatment. Significant data were recorded only for NSAID therapy. Thus, these patients showed a decrease in bacterial diversity, in Bifidobacterium and Lactobacillus and an increase in Bacteroides, C.coccoides, C.leptum, F.prausnitzii and E. coli.

Studies have shown that the intestinal microbiome can predict the therapeutic response and can be considered a 'biomarker' for inflammation (59). NSAID treatment may cause enteropathy $(60,61)$ or may aggravate intestinal inflammation in patients with IBD. Chronic administration of NSAIDs (celecoxib) had the ability to modulate intestinal microbiome, leading to a decrease in Bifidobacterium and Lactobacillus followed by an increase in Coriobacteriaceae, having also a chemoprotective role by decreasing fecal metabolites (62). Montenegro et al (63) support the harmful effect of NSAIDs, characterized by a marked reduction in Lactobacillus and by modulation of local motility and immunity through the Bifidobacteria group.

In the present study, in contrary, synthetic and biological immunosuppressive drugs had a positive effect on the intestinal microbiome, improving dysbiosis and decreasing systemic inflammation. Anti-TNF $\alpha$ agents can act on the intestinal microbiome by inhibiting the onset of vascular inflammation and by inducing $\mathrm{T}$ cell apoptosis (64). Other authors state that this improvement of the intestinal microbiome after $\mathrm{TNF} \alpha$ therapy is due to a decrease in bacterial arthritogenic peptides (65).

A study which included proteoglycan-induced mice treated with etanercept for 4 weeks demonstrated the efficacy of anti-TNF therapy on articular manifestations and on gut microbiome composition, leading even to a microbial composition similar to that of the control group (66). Another study (67) highlighted the changes in the intestinal microbiome of patients with AS at 1,3 and 6 months after initiating anti-TNF $\alpha$ therapy. Initially, a decreased biodiversity was observed, which improved almost to normal after the first month of treatment.

In conclusion, our findings indicate that the intestinal microbiome in patients with AS has a special signature characterized by an inflammatory status induced by the increase in some bacterial species associated with the decrease in other species. We demonstrated that the composition of the intestinal microbiome is influenced by numerous factors, among which genetic background, smoking status, inflammatory markers, disease phenotype and treatment play the most important roles. Our results are similar with those already published and participate in the enrichment of knowledge in the field, bringing new data on intestinal dysbiosis in patients with AS.

\section{Acknowledgements}

Not applicable.

\section{Funding}

No funding was received.

\section{Availability of data and materials}

The datasets used and/or analyzed during the current study are available from the corresponding author on reasonable request.

\section{Authors' contributions}

AC, ER and AMB conceived the study, the methodology and drafted the manuscript. ER supervised and designed the study. AC, SC, FP, AMB and CR contributed to the literature resources; and $\mathrm{AC}, \mathrm{AMB}, \mathrm{FP}$ and $\mathrm{ER}$ validated the data and data analysis. AC, SC, FP, AMB, CR and ER contributed to the review and editing; AC, AMB, SC, CR, FP and ER contributed to the approval of the final version of the manuscript. All authors have read and agreed to the published version of the manuscript.

\section{Ethics approval and consent to participate}

Approval was obtained from the Ethics Committees of the Grigore T Popa University of Medicine and Pharmacy and Rehabilitation Hospital Iasi from which the cases were selected. All the included cases expressed their informed consent to participate in the study.

\section{Patient consent for publication}

Not applicable.

\section{Competing interests}

The authors declare that they have no competing interests.

\section{References}

1. Taurog JD, Chhabra A and Colbert RA: Ankylosing spondylitis and axial spondyloarthritis. N Engl J Med 374: 2563-2574, 2016.

2. Brewerton DA, Hart FD, Nicholls A, Caffrey M, James DC and Sturrock RD: Ankylosing spondylitis and HL-A 27. Lancet 1: 904-907, 1973.

3. Brown MA, Kennedy LG, MacGregor AJ, Darke C, Duncan E, Shatford JL, Taylor A, Calin A and Wordsworth P: Susceptibility to ankylosing spondylitis in twins: The role of genes, HLA, and the environment. Arthritis Rheum 40: 1823-1828, 1997.

4. Manasson J, Shen N, Garcia Ferrer HR, Ubeda C, Iraheta I, Heguy A, Von Feldt JM, Espinoza LR, Garcia Kutzbach A, Segal LN, et al: Gut microbiota perturbations in reactive arthritis and postinfectious spondyloarthritis. Arthritis Rheumatol 70: 242-254, 2018.

5. Zhang Y, Guerassimov A, Leroux JY, Cartman A, Webber C, Lalic R, de Miguel E, Rosenberg LC and Poole AR: Arthritis induced by proteoglycan aggrecan G1 domain in BALB/c mice. Evidence for $t$ cell involvement and the immunosuppressive influence of keratan sulfate on recognition of $t$ and $b$ cell epitopes. J Clin Invest 101: 1678-1686, 1998.

6. Capkova J, Hrncir T, Kubatova A and Tlaskalova-Hogenova H: Lipopolysaccharide treatment suppresses spontaneously developing ankylosing enthesopathy in B10.BR male mice: The potential role of interleukin-10. BMC Musculoskelet Disord 13: 110, 2012.

7. Thjodleifsson B, Geirsson AJ, Björnsson S and Bjarnason I: A common genetic background for inflammatory bowel disease and ankylosing spondylitis: A genealogic study in Iceland. Arthritis Rheum 56: 2633-2639, 2007. 
8. Robinson PC,LeoPJ,Pointon JJ,Harris J,Cremin K, Bradbury LA, Stebbings S, Harrison AA; Australian Osteoporosis Genetics Consortium; Wellcome Trust Case Control Consortium, et al: Exome-wide study of ankylosing spondylitis demonstrates additional shared genetic background with inflammatory bowel disease. NPJ Genom Med 1: 16008, 2016.

9. Tsui FW, Tsui HW, Akram A, Haroon N and Inman RD: The genetic basis of ankylosing spondylitis: New insights into disease pathogenesis. Appl Clin Genet 7:105-115, 2014.

10. Costello ME, Ciccia F, Willner D, Warrington N, Robinson PC Gardiner B, Marshall M, Kenna TJ, Triolo G and Brown MA: Brief report: Intestinal dysbiosis in ankylosing spondylitis. Arthritis Rheumatol 67: 686-691, 2015.

11. Taurog JD, Richardson JA, Croft JT, Simmons WA, Zhou M, Fernández-Sueiro JL, Balish E and Hammer RE: The germfree state prevents development of gut and joint inflammatory disease in HLA-B27 transgenic rats. J Exp Med 180: 2359-2364, 1994.

12. Asquith MJ, Stauffer P, Davin S, Mitchell C, Lin P and Rosenbaum JT: Perturbed mucosal immunity and dysbiosis accompany clinical disease in a rat model of spondyloarthritis Arthritis Rheumatol 68: 2151-2162, 2016.

13. Lin P, Bach M, Asquith M, Lee AY, Akileswaran L, Stauffer P, Davin S, Pan Y, Cambronne ED, Dorris M, et al: HLA-B27 and human $\beta 2$-microglobulin affect the gut microbiota of transgenic rats. PLoS One 9: e105684, 2014.

14. Zhang L, Hu Y, Xu Y, Li P, Ma H, Li X and Li M: The correlation between intestinal dysbiosis and the development of ankylosing spondylitis. Microb Pathog 132: 188-192, 2019.

15. Turner MJ, Sowders DP, DeLay ML, Mohapatra R, Bai S, Smith JA, Brandewie JR, Taurog JD and Colbert RA: HLA-B27 misfolding in transgenic rats is associated with activation of the unfolded protein response. J Immunol 175: 2438-2448, 2005.

16. Kaneko $M$ and Nomura Y: ER signaling in unfolded protein response. Life Sci 74: 199-205, 2003.

17. Ciccia F, Accardo-Palumbo A, Rizzo A, Guggino G, Raimondo S, Giardina A, Cannizzaro A, Colbert RA, Alessandro R and Triolo G: Evidence that autophagy, but not the unfolded protein response, regulates the expression of IL-23 in the gut of patients with ankylosing spondylitis and subclinical gut inflammation. Ann Rheum Dis 73: 1566-1574, 2014

18. Ciccia F, Rizzo A and Triolo G: Subclinical gut inflammation in ankylosing spondylitis. Curr Opin Rheumatol 28: 89-96, 2016.

19. Tian P, Li B, He C, Song W, Hou A, Tian S, Meng X, Li K and Shan Y: Antidiabetic (type 2) effects of Lactobacillus G15 and Q14 in rats through regulation of intestinal permeability and microbiota. Food Funct 7: 3789-3797, 2016.

20. Morris G, Berk M, Carvalho AF, Caso JR, Sanz Y and Maes M: The role of microbiota and intestinal permeability in the pathophysiology of autoimmune and neuroimmune processes with an emphasis on inflammatory bowel disease type 1 diabetes and chronic fatigue syndrome. Curr Pharm Des 22: 6058-6075, 2016.

21. Ebringer A and Wilson C: The use of a low starch diet in the treatment of patients suffering from ankylosing spondylitis. Clin Rheumatol 15 (Suppl 1): S62-S66, 1996.

22. Ugur M, Baygutalp NK, Melikoglu MA, Baygutalp F, Altas EU and Seferoglu B: Elevated serum interleukin-23 levels in ankylosing spondylitis patients and the relationship with disease activity. Nagoya J Med Sci 77: 621-627, 2015

23. Smith JA and Colbert RA: Review: The interleukin-23/interleukin-17 ax is in spondyloarthritis pathogenesis: Th17 and beyond. Arthritis Rheumatol 66: 231-241, 2014.

24. Ciccia F, Guggino G, Rizzo A, Saieva L, Peralta S, Giardina A, Cannizzaro A, Sireci G, De Leo G, Alessandro R and Triolo G: Type 3 innate lymphoid cells producing IL-17 and IL-22 are expanded in the gut, in the peripheral blood, synovial fluid and bone marrow of patients with ankylosing spondylitis. Ann Rheum Dis 74: 1739-1747, 2015.

25. Costello ME, Elewaut D, Kenna TJ and Brown MA: Microbes, the gut and ankylosing spondylitis. Arthritis Res Ther 15: 214, 2013.

26. van der Linden S, Valkenburg HA and Cats A: Evaluation of diagnostic criteria for ankylosing spondylitis. A proposal for modification of the New York criteria. Arthritis Rheum 27: 361-368, 1984

27. Wang W, Chen L, Zhou R, Wang X, Song L, Huang S, Wang G and Xia B: Increased proportions of Bifidobacterium and the Lactobacillus group and loss of butyrate-producing bacteria in inflammatory bowel disease. J Clin Microbiol 52: 398-406, 2014.
28. Zhang L, Han R, Zhang X, Fang G, Chen J, Li J, Xu S, Qian L, Chen W and Pan F: Fecal microbiota in patients with ankylosing spondylitis: Correlation with dietary factors and disease activity. Clin Chim Acta 497: 189-196, 2019.

29. Breban M, Tap J, Leboime A, Said-Nahal R, Langella P, Chiocchia G, Furet JP and Sokol H: Faecal microbiota study reveals specific dysbiosis in spondyloarthritis. Ann Rheum Dis 76: 1614-1622, 2017.

30. Morgan XC, Tickle TL, Sokol H, Gevers D, Devaney KL, Ward DV, Reyes JA, Shah SA, LeLeiko N, Snapper SB, et al: Dysfunction of the intestinal microbiome in inflammatory bowel disease and treatment. Genome Biol 13: R79, 2012.

31. Scher JU, Ubeda C, Artacho A, Attur M, Isaac S, Reddy SM, Marmon S, Neimann A, Brusca S, Patel T, et al: Decreased bacterial diversity characterizes the altered gut microbiota in patients with psoriatic arthritis, resembling dysbiosis in inflammatory bowel disease. Arthritis Rheumatol 67: 128-139, 2015.

32. Tito RY, Cypers H, Joossens M, Varkas G, Van Praet L, Glorieus E, Van den Bosch F, De Vos M, Raes J and Elewaut D: Brief report: Dialister as a microbial marker of disease activity in spondyloarthritis. Arthritis Rheumatol 69: 114-121, 2017.

33. Haque TR and Barritt AS IV: Intestinal microbiota in liver disease. Best Pract Res Clin Gastroenterol 30: 133-142, 2016.

34. Minemura M and Shimizu Y: Gut microbiota and liver diseases. World J Gastroenterol 21: 1691-1702, 2015.

35. Morris A: Metabolism: New insights into the BAT-liver-gut axis. Nat Rev Endocrinol 13: 438, 2017.

36. Yip LY, Aw CC, Lee SH, Hong YS, Ku HC, Xu WH, Chan JMX, Cheong EJY, Chng KR, Ng AHQ, et al: The liver-gut microbiota axis modulates hepatotoxicity of tacrine in the rat. Hepatology 67: 282-295, 2018.

37. Pallen MJ and Quraishi MN: The gut microbiota and the hepatologist: Will our bugs prove to be the missing link? Dig Dis 35: 377-383, 2017.

38. Rabb H, Pluznick $\mathbf{J}$ and Noel S: The microbiome and acute kidney injury. Nephron 140: 120-123, 2018.

39. Noel S, Martina-Lingua MN, Bandapalle S, Pluznick J, Hamad AR, Peterson DA and Rabb H: Intestinal microbiota-kidney cross talk in acute kidney injury and chronic kidney disease. Nephron Clin Pract 127: 139-143, 2014.

40. Sabatino A, Regolisti G, Brusasco I, Cabassi A, Morabito S and Fiaccadori E: Alterations of intestinal barrier and microbiota in chronic kidney disease. Nephrol Dial Transplant 30: 924-933, 2015.

41. Ostan R, Béné MC, Spazzafumo L, Pinto A, Donini LM, Pryen F, Charrouf Z, Valentini L, Lochs H, Bourdel-Marchasson I, et al: Impact of diet and nutraceutical supplementation on inflammation in elderly people. Results from the RISTOMED study, an open-label randomized control trial. Clin Nutr 35: 812-818, 2016.

42. Valentini L, Pinto A, Bourdel-Marchasson I, Ostan R, Brigidi P, Turroni S, Hrelia S, Hrelia P, Bereswill S, Fischer A, et al: Impact of personalized diet and probiotic supplementation on inflammation, nutritional parameters and intestinal microbiota-The 'RISTOMED project': Randomized controlled trial in healthy older people. Clin Nutr 34: 593-602, 2015.

43. Klingberg E, Magnusson MK, Strid H, Deminger A, Ståhl A, Sundin J, Simrén M, Carlsten H, Öhman L and Forsblad-d'Elia H: A distinct gut microbiota composition in patients with ankylosing spondylitis is associated with increased levels of fecal calprotectin. Arthritis Res Ther 21: 248, 2019.

44. Rizzatti G, Lopetuso LR, Gibiino G, Binda C and Gasbarrini A: Proteobacteria: A common factor in human diseases. Biomed Res Int 2017: 9351507, 2017.

45. McIlroy J, Ianiro G, Mukhopadhya I, Hansen R and Hold GL: Review article: The gut microbiome in inflammatory bowel disease-avenues for microbial management. Aliment Pharmacol Ther 47: 26-42, 2018.

46. Ciccia F, Guggino G, Rizzo A, Alessandro R, Luchetti MM, Milling S, Saieva L, Cypers H, Stampone T, Di Benedetto P, et al: Dysbiosis and zonulin upregulation alter gut epithelial and vascular barriers in patients with ankylosing spondylitis. Ann Rheum Dis 76: 1123-1132, 2017.

47. Klingberg E, Strid H, Ståhl A, Deminger A, Carlsten H, Öhman L and Forsblad-d'Elia H: A longitudinal study of fecal calprotectin and the development of inflammatory bowel disease in ankylosing spondylitis. Arthritis Res Ther 19: 21, 2017. 
48. Van Praet L, Jans L, Carron P, Jacques P, Glorieus E, Colman R, Cypers H, Mielants H, De Vos M, Cuvelier C, et al: Degree of bone marrow oedema in sacroiliac joints of patients with axial spondyloarthritis is linked to gut inflammation and male sex: Results from the GIANT cohort. Ann Rheum Dis 73: 1186-1189, 2014.

49. Onderdonk AB, Richardson JA, Hammer RE and Taurog JD: Correlation of cecal microflora of HLA-B27 transgenic rats with inflammatory bowel disease. Infect Immun 66: 6022-6023, 1998.

50. Aron-Wisnewsky J, Prifti E, Belda E, Ichou F, Kayser BD, Dao MC, Verger EO, Hedjazi L, Bouillot JL, Chevallier JM, et al: Major microbiota dysbiosis in severe obesity: Fate after bariatric surgery. Gut 68: 70-82, 2019.

51. Ley RE, Turnbaugh PJ, Klein S and Gordon JI: Microbial ecology: Human gut microbes associated with obesity. Nature 444: 1022-1023, 2006.

52. Ley RE, Bäckhed F, Turnbaugh P, Lozupone CA, Knight RD and Gordon JI: Obesity alters gut microbial ecology. Proc Natl Acad Sci USA 102: 11070-11075, 2005.

53. Kasai C, Sugimoto K, Moritani I, Tanaka J, Oya Y, Inoue H, Tameda M, Shiraki K, Ito M, Takei Y and Takase K: Comparison of the gut microbiota composition between obese and non-obese individuals in a Japanese population, as analyzed by terminal restriction fragment length polymorphism and next-generation sequencing. BMC Gastroenterol 15: 100, 2015.

54. Angelakis E, Armougom F, Carrière F, Bachar D, Laugier R, Lagier JC, Robert C, Michelle C, Henrissat B and Raoult D: A metagenomic investigation of the duodenal microbiota reveals links with obesity. PLoS One 10: e0137784, 2015.

55. Hu HJ, Park SG, Jang HB, Choi MK, Park KH, Kang JH, Park SI, Lee HJ and Cho SH: Obesity alters the microbial community profile in Korean adolescents. PLoS One 10: e0134333, 2015.

56. Parkes GC, Whelan K and Lindsay JO: Smoking in inflammatory bowel disease: Impact on disease course and insights into the aetiology of its effect. J Crohn's Colitis 8: 717-725, 2014.

57. Savin Z, Kivity S, Yonath $\mathrm{H}$ and Yehuda S: Smoking and the intestinal microbiome. Arch Microbiol 200: 677-684, 2018.

58. Chen Z, Qi J, Wei Q, Zheng X, Wu X, Li X, Liao Z, Lin Z and $\mathrm{Gu}$ J: Variations in gut microbial profiles in ankylosing spondylitis: Disease phenotype-related dysbiosis. Ann Transl Med 7: 571, 2019.

59. Kolho KL, Korpela K, Jaakkola T, Pichai MV, Zoetendal EG, Salonen A and de Vos WM: Fecal microbiota in pediatric inflammatory bowel disease and its relation to inflammation. Am J Gastroenterol 110: 921-930, 2015.
60. Wallace JL: NSAID gastropathy and enteropathy: Distinct pathogenesis likely necessitates distinct prevention strategies. Br J Pharmacol 165: 67-74, 2012.

61. Wallace JL: Mechanisms, prevention and clinical implications of nonsteroidal anti-inflammatory drug-enteropathy. World J Gastroenterol 19: 1861-1876, 2013.

62. Montrose DC, Zhou XK, McNally EM, Sue E, Yantiss RK, Gross SS, Leve ND, Karoly ED, Suen CS, Ling L, et al: Celecoxib alters the intestinal microbiota and metabolome in association with reducing polyp burden. Cancer Prev Res (Phila) 9: 721-731, 2016.

63. Montenegro L, Losurdo G, Licinio R, Zamparella M, Giorgio F, Ierardi E, Di Leo A and Principi M: Non steroidal anti-inflammatory drug induced damage on lower gastro-intestinal tract: Is there an involvement of microbiota? Curr Drug Saf 9: 196-204, 2014.

64. Danese S, Sans M, Scaldaferri F, Sgambato A, Rutella S, Cittadini A, Piqué JM, Panes J, Katz JA, Gasbarrini A and Fiocchi C: TNF-alpha blockade down-regulates the CD40/CD40L pathway in the mucosal microcirculation: A novel anti-inflammatory mechanism of infliximab in Crohn's disease. J Immunol 176: 2617-2624, 2006.

65. Yin J, Sternes PR, Wang M, Song J, Morrison M, Li T, Zhou L, $\mathrm{Wu} \mathrm{X}, \mathrm{He} \mathrm{F}, \mathrm{Zhu} \mathrm{J}$, et al: Shotgun metagenomics reveals an enrichment of potentially cross-reactive bacterial epitopes in ankylosing spondylitis patients, as well as the effects of TNFi therapy upon microbiome composition. Ann Rheum Dis 79: 132-140, 2020

66. Liu B, Yang L, Cui Z, Zheng J, Huang J, Zhao Q, Su Z, Wang M, Zhang W, Liu J, et al: Anti-TNF- $\alpha$ therapy alters the gut microbiota in proteoglycan-induced ankylosing spondylitis in mice. Microbiologyopen 8: e927, 2019.

67. Zhang F, Ma C and Zhang B: Dynamic variations in gut microbiota in ankylosing spondylitis patients treated with anti-TNF- $\alpha$ for six months. Ann Clin Lab Sci 50: 99-106, 2020.

(i) $\Theta$ This work is licensed under a Creative Commons Attribution-NonCommercial-NoDerivatives 4.0 International (CC BY-NC-ND 4.0) License. 